\section{Carbon Dioxide Enrichment May Increase Yield of Field-grown Red Raspberry under High Tunnels}

\author{
Maren J. Mochizuki ${ }^{1}$, Oleg Daugovish ${ }^{1,5}$, Miguel H. Ahumada ${ }^{2}$, \\ Shawn Ashkan ${ }^{3}$, and Carol J. Lovatt ${ }^{4}$
}

AdDitional INDEX wORDs. Rubus idaeus, photosynthesis, greenhouse gas

SUMMARY. The objectives of this preliminary study were to optimize a carbon dioxide $\left(\mathrm{CO}_{2}\right)$ application system for field-grown raspberry ( $R u b u s$ ideaus) under high tunnels and then to compare plant photosynthesis, growth, and fruit yield with and without $\mathrm{CO}_{2}$. Based on plant photosynthesis measures before $\mathrm{CO}_{2}$ application, we placed the drip irrigation tape to apply $\mathrm{CO}_{2}$ in the middle of the plant canopy at 100 $\mathrm{cm}$ aboveground and split daily $\mathrm{CO}_{2}$ application from 0700 to $1100 \mathrm{HR}$ and 1400 to $1800 \mathrm{HR}$. In the morning hours, $\mathrm{CO}_{2}$ concentration in the tunnel was $18 \%$ higher than in the afternoon; wind speed often increased later in the day, which may have moved the $\mathrm{CO}_{2}$ even in the tunnel. We maintained an average $\mathrm{CO}_{2}$ concentration of 436 ppm for 4 months, applying about 25 tons of $\mathrm{CO}_{2}$. In tunnels enriched with $\mathrm{CO}_{2}$, yield and berry size from plots $20 \mathrm{ft}$ in length increased $12 \%$ and $5 \%$, respectively, compared with untreated tunnels. We measured no corresponding differential response in the number of $6-\mathrm{oz}$ baskets harvested from the full tunnel, leaf $\mathrm{CO}_{2}$ assimilation, stomatal conductance $\left(g_{s}\right)$, or fluorescence, raspberry cane height, pruned cane biomass, cane diameter, or carbohydrate content of the fruit after $\mathrm{CO}_{2}$ application. Documenting potential plant physiological changes should therefore be a focus of future research.

$\mathrm{M}$ ore than 7 billion tons of greenhouse gases (GHG) were released in the United States in 2006 ; about $85 \%$ was carbon dioxide primarily attributable to the combustion of fossil fuels for the generation of electricity and for transportation [U.S. Environmental Protection Agency (USEPA), 2008]. In response, nearly all members of the United Nations, including the United States, have pledged to "prevent dangerous anthropogenic interference with the climate system" by stabilizing the concentration of GHG in atmosphere that contribute to the greenhouse effect (USEPA, 2008).

This research was funded in part by the University of California Hansen Trust.

We thank Yusheng Zheng and Toan Khuong for their technical assistance and acknowledge Ben Faber and Jim Downer for editorial assistance.

${ }^{1}$ University of California Cooperative Extension, Ventura County, 669 County Square Drive, Ventura, CA 93003

${ }^{2}$ Driscoll's Strawberry Associates, Inc., 1317 Del Norte Road, Camarillo, CA 93010

${ }^{3}$ Center for Irrigation Technology, California State University, Fresno, 5370 North Chestnut Avenue, Fresno, CA 93740

${ }^{4}$ Department of Botany and Plant Sciences-072, University of California, Riverside, Riverside, CA 925210124

${ }^{5}$ Corresponding author. E-mail: odaugovish@ucdavis. edu.
One way to mitigate $\mathrm{CO}_{2}$ release is to capture emissions. The cost to implement this technology is substantial, ranging from $\$ 30$ to $\$ 40$ per ton of $\mathrm{CO}_{2}$ (Miracca, 2006); research aimed at lowering these costs is currently underway with support from eight major energy companies, the U.S. Department of Energy, the European Union, and the Research Council of Norway (Brownscombe, 2006).

While current $\mathrm{CO}_{2}$ capture technology focuses on geological storage (CO2 Capture Project, 2008), an incentive to capture emissions may be offered by agriculture: $\mathrm{CO}_{2}$ could be supplied to plants for uptake and sequestration as an alternative to underground storage. However, a substantive benefit of $\mathrm{CO}_{2}$ application must be demonstrated for growers to consider the practice and become advocates of industrial $\mathrm{CO}_{2}$ recycling.

Commercial raspberry production, in particular, may be a model system for $\mathrm{CO}_{2}$ sequestration. First, raspberry plants have a large, multilayered plant canopy to readily intercept applied $\mathrm{CO}_{2}$. Raspberry canes are woody, which are a greater carbon sink than many herbaceous crop plants (Sauerbeck, 2001). For example, 'Heritage' raspberry plants showed an increase in photosynthetic efficiency with elevated $\mathrm{CO}_{2}$ levels and were more sensitive to $\mathrm{CO}_{2}$ levels compared with other species with C3 photosynthetic pathways, such as rose (Rosa spp.) and carnation (Dianthus carophyllus) (Percival et al., 1996).

In addition to plant morphological and physiological considerations, the typical growing season and standard production practices make raspberry a strong candidate for successful $\mathrm{CO}_{2}$ application. In growing areas with relatively mild winters and cool summers such as Portugal, an "offseason" production model is followed, entailing a summer cutting of primocane-fruiting varieties to extend harvest into the fall (Oliveira et al., 1996). The production season is similar in coastal southern California, spanning about 24 months with four harvests that provide fruit between October and May (Gaskell, 2004). Compared with annual crops, then, the off-season raspberry production system has potential for longer $\mathrm{CO}_{2}$ exposure times and fewer expenses associated with the installation or removal of an application system. Plants may be maintained even longer in other production areas such as Ontario, where primocane varieties were successfully fruited for up to 3 years in greenhouses (Dale et al., 2003), or Michigan and the northeastern United States, where

\begin{tabular}{llll}
\hline $\begin{array}{l}\text { Units } \\
\text { To convert U.S. to SI, } \\
\text { multiply by }\end{array}$ & U.S. unit & SI unit & $\begin{array}{l}\text { To convert SI to U.S., } \\
\text { multiply by }\end{array}$ \\
\hline 0.4047 & acre(s) & ha & 2.4711 \\
0.3048 & $\mathrm{ft}$ & $\mathrm{m}$ & 3.2808 \\
2.54 & inch(es) & $\mathrm{cm}$ & 0.3937 \\
0.0254 & $\mathrm{mil}$ & $\mathrm{mm}$ & 39.3701 \\
28.3495 & $\mathrm{oz}$ & $\mathrm{g}$ & 0.0353 \\
1 & $\mathrm{ppm}$ & $\mu \mathrm{LL} \cdot \mathrm{L}^{-1}$ & 1 \\
6.8948 & $\mathrm{psi}$ & $\mathrm{kPa}$ & 0.1450 \\
0.9072 & ton(s) & $\mathrm{Mg}$ & 1.1023 \\
$\left({ }^{\circ} \mathrm{F}-32\right) \div 1.8$ & ${ }^{\circ} \mathrm{F}$ & ${ }^{\circ} \mathrm{C}$ & $\left(1.8 \times{ }^{\circ} \mathrm{C}\right)+32$
\end{tabular}


plant productivity was estimated to be 7 and 10 years, respectively, in budget projections for high tunnel production (Hanson et al., 2008; Heidenreich et al., 2008). Existing infrastructure such as cane support wires can hold the drip irrigation tape supplying $\mathrm{CO}_{2}$. Finally, and perhaps, most importantly, high tunnels are currently used in coastal southern California and many other production areas including the north central, south central, and northeastern United States and Portugal, to create more favorable environmental conditions for early harvest or season extension (Friedrich et al., 2009; Hanson et al., 2008; Heidenreich et al., 2008; Oliveira et al., 1996). For $\mathrm{CO}_{2}$ application, high tunnels may minimize loss of $\mathrm{CO}_{2}$ due to wind, which was the principal factor reducing the effectiveness of the system tested for annual strawberry (Fragaria Xananassa) (S. Ashkan, personal communication).

Furthermore, raspberry is a highvalue crop for which production has been increasing in California every year since 1998 [California Department of Food and Agriculture (CDFA), 2007]. In 2006, an estimated 4300 acres was in production, with a value of $\$ 58,000$ per acre compared with $\$ 33,000$ per acre for strawberry (CDFA, 2007).

While numerous studies provide evidence of the physiological effect of elevated $\mathrm{CO}_{2}$ concentration on many plant species in growth chambers, research on raspberry examined physiological processes such as photosynthesis, but yield (Percival et al., 1996) and $\mathrm{CO}_{2}$ enrichment for field-grown raspberry is not represented in the literature. In a strawberry field study under tunnels at Irvine, CA, yield increased as much as $13 \%$ with $\mathrm{CO}_{2}$ concentrations ranging between 700 and $1000 \mathrm{ppm}$ or about double and triple ambient conditions, respectively (Hartz et al., 1991). Early yield (the first 4 weeks of harvest) was also increased (Hartz et al., 1991). Plant biomass and fruit yield for potted strawberry in "semi-open polyethylene chambers" increased $21 \%$ and $17 \%$, respectively, with a constant $\mathrm{CO}_{2}$ concentration of 1000 ppm (Acuña-Maldonado and Pritts, 2008). Additionally, $\mathrm{CO}_{2}$ enrichment significantly increased endogenous concentrations of antioxidants and ascorbic acid (vitamin C) for field-grown strawberries (Wang et al., 2003), a potential health benefit for consumers.

In another open-air study, a $\mathrm{CO}_{2}$ concentration of $700 \mathrm{ppm}$ under tunnels increased tomato (Solanum lycopersicum) yields $30 \%$ at Irvine, CA (Hartz et al., 1991). Other vegetables grown under plastic tunnels such as cucumber (Cucumis sativus) and squash (Cucurbita pepo) had yield tween $18 \%$ and $70 \%$ and earlier bloom and fruit set with $\mathrm{CO}_{2}$ delivered through drip irrigation tape (Hartz et al., 1991).

Because there were no published investigations of $\mathrm{CO}_{2}$ application for field-grown raspberry, the first objective of this research was to optimize a $\mathrm{CO}_{2}$ delivery for this specific production system. We also wanted to evaluate the effects of $\mathrm{CO}_{2}$ application on raspberry growth and yield. A successful agricultural delivery system resulting in yield enhancement may further drive the development of technology for $\mathrm{CO}_{2}$ capture and recycling.

\section{Materials and methods}

The study area comprised 13 high tunnels in a commercial raspberry field located near Camarillo, CA. Each tunnel measured $18 \mathrm{ft}$ wide and $300 \mathrm{ft}$ long and was covered with 5-mil polyethylene film (Poly-Ag, San Diego). The soil was Hueneme sandy loam (coarse-loamy, mixed, superactive, calcareous, thermic Oxyaquic Xerofluvents) (U.S. Department of Agriculture, 1997). Three rows of a proprietary variety of primocane red raspberry were planted on $6-\mathrm{ft}$ centers in each tunnel in Apr. 2006, resulting in a density of about 17 canes per meter of row when counted in May 2007. Irrigation, fertilization, and pest management were conducted according to standard practices. Primocane fruit was harvested and dry weight increases ranging be-

from Sept. to Nov. 2006. In Jan. 2007, we randomly designated tunnels that would later receive $\mathrm{CO}_{2}$, which were separated from control treatments (no $\mathrm{CO}_{2}$ applied) by buffer tunnels (Fig. 1). The experimental design was completely randomized with three replications per treatment.

Construction OF $\mathrm{CO}_{2}$ APPLICATION SYSTEM. Food-grade liquid $\mathrm{CO}_{2}$ was housed on the property in a 10 -ton tank measuring $20 \times 8 \times$ $8 \mathrm{ft}$, which rested atop four thick planks. The tank was filled to capacity about every $45 \mathrm{~d}$ at a cost of about $\$ 300$ per ton (Airgas West, Lakewood, CA). The tank was connected to an ambient vaporizer that warmed the liquid, vaporizing it into gas. The gas flow rate was measured using a root gas meter and electronic gas volume corrector (Mini-AT; Mercury Instruments, Cincinnati). The gas moved through $550 \mathrm{ft}$ of polyvinyl chloride (PVC) pipe to the three raspberry tunnels. At each tunnel entrance, the PVC pipe was connected to black plastic tubing and then to ultralow-flow drip irrigation tape with 8-inch emitter spacing ( $\mathrm{T}$ tape; T Systems, San Diego), suspended within the raspberry canopy for the entire length of the tunnel. To ensure gas was flowing through the length of the tunnel, we checked the ends of the drip tape on a weekly basis by feeling the pressure of gas flow on the walls of the tape [about 2 psi (without gas flow, drip tape walls were not taut)] and by listening for the sound of gas flow through the tape. We applied about 25 tons of $\mathrm{CO}_{2}$ between 15 May and 24 Oct.

In two of the three tunnels receiving $\mathrm{CO}_{2}$, we placed gas analyzer sensors (WMA-4; PP Systems, Amesbury, MA) within the raspberry canopy at about $120 \mathrm{~cm}$ aboveground. The gas analyzers recorded $\mathrm{CO}_{2}$ concentration every $30 \mathrm{~s}$ and were connected to a datalogger (CR 10X;

\begin{tabular}{|c|c|c|c|c|c|c|c|c|c|c|c|c|c|}
\hline Treatment & $\mathrm{X}$ & $\mathrm{CO}_{2}$ & $\mathrm{X}$ & $\begin{array}{c}\mathrm{No} \\
\mathrm{CO}_{2}\end{array}$ & $\mathrm{X}$ & $\begin{array}{l}\mathrm{No} \\
\mathrm{CO}_{2}\end{array}$ & $\mathrm{X}$ & $\mathrm{CO}_{2}$ & $\mathrm{X}$ & $\mathrm{CO}_{2}$ & $\mathrm{X}$ & $\mathrm{X}$ & $\begin{array}{l}\text { No } \\
\mathrm{CO}_{2}\end{array}$ \\
\hline Tunnel & 1 & 2 & 3 & 4 & 5 & 6 & 7 & 8 & 9 & 10 & 11 & 12 & 13 \\
\hline
\end{tabular}

Fig. 1. Experimental design for carbon dioxide $\left(\mathrm{CO}_{2}\right)$ application to raspberry under high tunnels near Camarillo, CA, was completely randomized with three replications per treatment. An " $X$ " indicates buffer tunnels that separated treatments. 
Campbell Scientific, Logan, UT) that output an average reading each minute.

Photosynthesis parameters. We measured photosynthetic photon flux (PPF) (LI-189; LI-COR, Lincoln, NE), leaf stomatal conductance $\left(g_{S}\right)$, leaf $\mathrm{CO}_{2}$ assimilation, air temperature (TPS-1, PP Systems), and leaf fluorescence (Handy PEA; Hansatech Instruments, King's Lynn, $\mathrm{UK}$ ) in January, before $\mathrm{CO}_{2}$ was applied to determine where to locate the tape within the canopy for $\mathrm{CO}_{2}$ application, in June, at the start of $\mathrm{CO}_{2}$ application and second harvest (floricanes), and in September, at the third harvest, which was 1 month before ending $\mathrm{CO}_{2}$ application. Three young, fully expanded, healthy green leaves were selected at three canopy heights-40,80, and 120 $\mathrm{cm}$ from the ground-on each of six plants per treatment in the center row of each tunnel or at the outer surface of the plant canopy in the case of air temperature. In January, photosynthetic parameters were determined for all leaves every hour from sunrise to late afternoon on the side of the row with the highest PPF. For subsequent sampling dates, measurements were conducted during the morning hours only because we determined in our full-day measurements that the morning hours had the highest rates of $g_{S}$ and $\mathrm{CO}_{2}$ assimilation.

Measuring plant baseline CONDITIONS AND RESPONSE TO $\mathbf{C O}_{2}$ APPLICATION. Before $\mathrm{CO}_{2}$ application, we counted the total number of floricanes and measured their height in two randomly selected 20$\mathrm{ft}$ subplots in the center row of each tunnel. We also determined fruit yield in each plot, the average berry weight of 25 randomly selected fruit, and the number of 6-oz baskets harvested from the full tunnel length for the duration of commercial harvest from 26 May to 15 June. We repeated the cane height measurements after 2 months of $\mathrm{CO}_{2}$ application in July, before the pruning of floricanes that had finished fruiting. We also measured the pruned floricane biomass (fresh weight) from each plot. For the third harvest from 12 Sept. to 30 Oct., we repeated all yield measurements. Yields for the $\mathrm{CO}_{2}$ treatment are reported as percentages of the untreated control in accordance with an agreement made with our grower collaborator. We also pureed the 25 fruit from each plot and measured soluble solids using a portable refractometer (model RHB-32ATC; Westover Scientific, Mill Creek, WA). The remaining puree was frozen before analysis of free glucose, fructose, and sucrose using high-performance liquid chromatography (HPLC), total glucose by enzymatic hydrolysis followed by HPLC, and total nonstructural carbohydrates and starch derived by calculations from analysis results (University of California Division of Agriculture and Natural Resources Analytical Laboratory, Davis). Finally, in December, we measured cane diameter in the research plots using calipers at the soil surface.

Statistical analysis. Data were analyzed using the General Linear Model (GLM) Procedure in SAS (version 9; SAS Institute, Cary, NC). The overall error rate was controlled by Tukey-Kramer adjustment. We validated the assumptions of normal distribution and equal variance using diagnostic plots generated by the GLM procedure.

Repeated-measures analysis was conducted also using the GLM procedure to determine effects of canopy height on $P P F, g_{S}, C_{2}$ assimilation, and leaf fluorescence $\left(\mathrm{F}_{\mathrm{v}} / \mathrm{F}_{\mathrm{m}}\right)$ from $0830 \mathrm{HR}$ to $1630 \mathrm{HR}$, with time as the repeated-measure factor and means separation by Duncan's multiple range test. Air temperature was analyzed using the GLM procedure with means separation by Fisher's least significant difference test.

\section{Results and discussion}

OP Timization OF $\mathrm{CO}_{2}$ application system. Photosynthesis parameters for plants in the tunnels were determined before $\mathrm{CO}_{2}$ was applied. $P P F$ was typically $20 \%$ lower in the tunnels than outside (data not shown). In other research, photosynthetically active radiation under plastic that was reused in the second year of the season, similar to this study, was $50 \%$ of outdoor irradiance (Daugovish and Larson, 2009). As light within the tunnels approached $50 \%$ full sunlight, $P P F$ decreased proportionally from the uppermost leaves $120 \mathrm{~cm}$ aboveground to the lower leaves $40 \mathrm{~cm}$ aboveground (Fig. 2A). Averaged between 0830 and
$1630 \mathrm{HR}, P P F$ at $120 \mathrm{~cm}$ was $56 \%$ greater than at $80 \mathrm{~cm} ; P P F$ at $80 \mathrm{~cm}$ was $58 \%$ greater than for leaves at 40 $\mathrm{cm}$ (Table $1, P<0.0001$ ). Mid and lower leaves were likely shaded by leaves higher in the canopy, which received the most sun.

Leaves at the top and middle of the canopy had similar $g_{S}$ rates, about $25 \%$ higher than for lower leaves when averaged for the day (Table 1 , $P=0.0048)$. Midday decline in $g_{S}$ was observed for leaves at all three canopy heights, including a $48 \%$ reduction between 1130 and 1230 HR for the topmost leaves (Fig. 2B). This midday depression in $\mathscr{g}_{S}$ has been documented in 'Titan' red raspberry and other woody plants (Fernandez and Pritts, 1994). Stomates likely close to prevent excessive transpiration in response to high irradiance (Fig. 2A), causing increased leaf temperature; air temperatures during this period increased by more than $3{ }^{\circ} \mathrm{C}$ (Table 2). Compared with outside the tunnel, air temperatures under high tunnels in south coastal California were 1 to $3{ }^{\circ} \mathrm{C}$ greater at all hours of the day during $\mathrm{l}$ year but 2 to $4{ }^{\circ} \mathrm{C}$ lower during the day and 2 to $3{ }^{\circ} \mathrm{C}$ higher at night in the second year, probably because of reduced irradiance levels in the tunnel due to reuse of the weathered polyethylene tunnel cover (Daugovish and Larson, 2009).

Leaves at $80 \mathrm{~cm}$ aboveground had an average $\mathrm{CO}_{2}$ assimilation rate about $60 \%$ higher than leaves at 120 or $40 \mathrm{~cm}$ (Table $1, P=0.0038) . \mathrm{CO}_{2}$ assimilation at this height was maintained at a higher rate compared with the other canopy heights throughout most of the day (Fig. 2C). In the early afternoon, when assimilation and conductance rates were similar at all leaf heights, air temperatures at the outer surface of the canopy were the highest of the whole day and similar between 80 and $120 \mathrm{~cm}$ height (Table 2).

Although the ratio of variable fluorescence to maximum fluorescence $\left(\mathrm{F}_{\mathrm{v}} / \mathrm{F}_{\mathrm{m}}\right)$ was highest $\left(\mathrm{F}_{\mathrm{v}} / \mathrm{F}_{\mathrm{m}}=\right.$ 0.8 ) for leaves at $40 \mathrm{~cm}$ height compared with leaves at 80 and $120 \mathrm{~cm}$ heights when averaged for the day $\left[\mathrm{F}_{\mathrm{v}} / \mathrm{F}_{\mathrm{m}}=0.78\right.$ (Table $1, P=$ $0.032)$ ], this $3 \%$ difference is likely not physiologically significant because a typical leaf has an efficiency of about $80 \% \quad\left(\mathrm{~F}_{\mathrm{v}} / \mathrm{F}_{\mathrm{m}}=0.8\right)$ (Carpentier, 2005; Schreiber, 2004). 
A

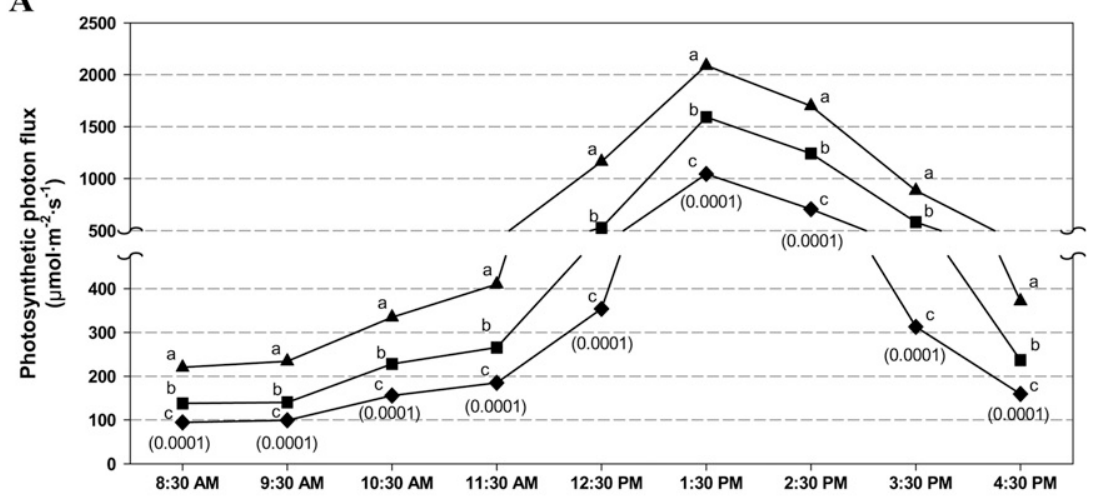

B

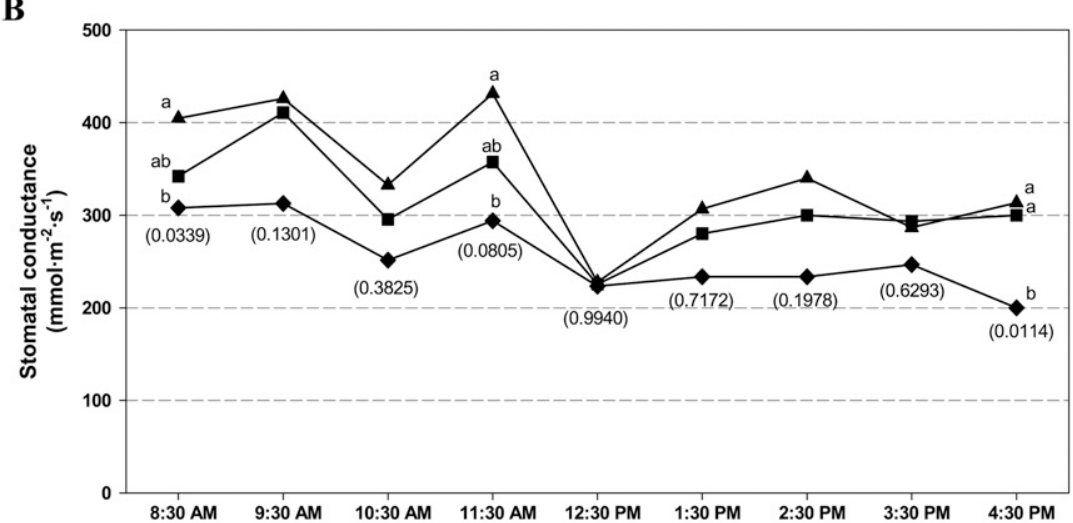

C
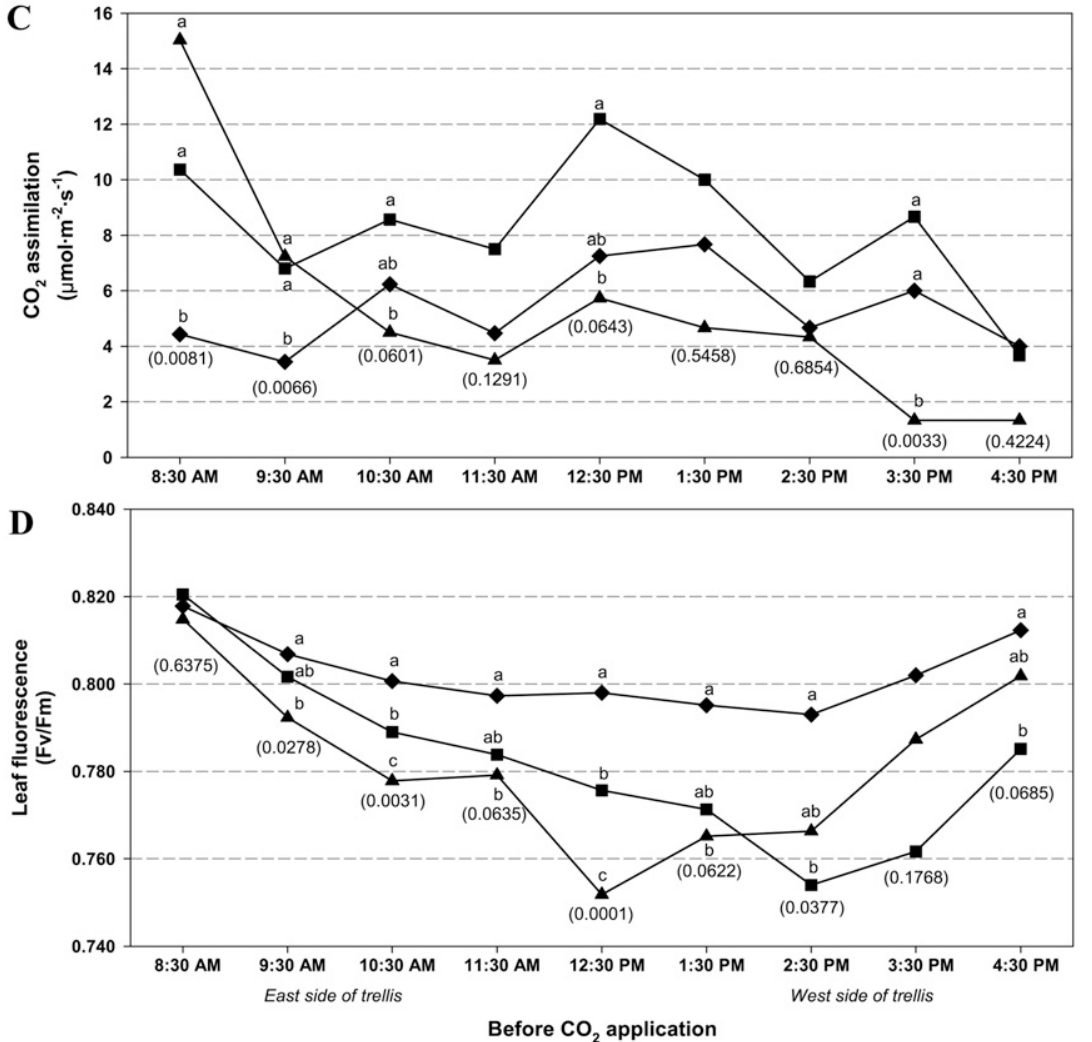

Fig. 2. $P P F$ density (A), leaf $g_{\mathrm{s}}(\mathrm{B})$, leaf $\mathrm{CO}_{2}$ assimilation (C), and leaf fluorescence (D) at $120 \mathrm{~cm}(\triangle), 80 \mathrm{~cm}(-)$, and $40 \mathrm{~cm}(\bullet)$ aboveground $(1 \mathrm{~cm}=0.3937$ inch) in the canopy of raspberry plants under high tunnels before $\mathrm{CO}_{2}$ application near Camarillo, CA. Values reported at each hour are the mean result for measurements made on one leaf at each height on each of three plants along the trellis in two separate tunnels $(n=6)$. The same letters at each time denote nonsignificant comparisons at $P<0.10$ using Duncan's multiple range test.
The ratio of $\mathrm{F}_{\mathrm{v}} / \mathrm{F}_{\mathrm{m}}$ provides an estimate of the energy conversion efficiency in Photosystem II. In this study, only leaves at $120 \mathrm{~cm}$ during midday had leaf fluorescence values $\left(\mathrm{F}_{\mathrm{v}} / \mathrm{F}_{\mathrm{m}}=0.75\right)($ Fig. 2D) and corresponding reduced rates of $\mathrm{CO}_{2}$ assimilation (Fig. 2C) that suggest leaf stress and potential damage from excess light energy, possibly as heat (Ralph, 2005; Schreiber, 2004). Air temperature at the top of the canopy was generally higher throughout the day than at mid and lower canopy heights (Table 2).

Based on these results, we chose to apply $\mathrm{CO}_{2}$ at a height of $100 \mathrm{~cm}$, where leaves had the highest rate of $\mathrm{CO}_{2}$ assimilation and were efficient at using available light energy. Furthermore, applying $\mathrm{CO}_{2}$ in the middle of the canopy allowed for interception by lower leaves during periods of minimum air movement when gas would move downward with gravity and also accommodated increasing plant height through the growing season. Due to the observed midday reduction in $g_{s}$ for leaves at all heights in the canopy and reduced efficiency of Photosystem II during the midday, we chose to apply $\mathrm{CO}_{2}$ between 0700 and 1100 HR again between 1400 and $1800 \mathrm{HR}$.

Once $\mathrm{CO}_{2}$ application began in June, we maintained an average concentration of $436 \mathrm{ppm}(\mathrm{SE}=19 \mathrm{ppm})$ or about $18 \%$ above ambient conditions $(370 \mathrm{ppm})$ for 4 months. $\mathrm{CO}_{2}$ concentration under the tunnel averaged 471 ppm $(\mathrm{SE}=27)$, or $18 \%$ higher in the morning hours compared with the afternoon which was $401 \mathrm{ppm}(\mathrm{sE}=11)$, possibly because air movement within the tunnel often increased in the afternoon. In an attempt to increase $\mathrm{CO}_{2}$ concentration under the tunnel, we increased the duration of $\mathrm{CO}_{2}$ application from $8 \mathrm{~h}$ to $12 \mathrm{~h}$ in mid-September for $\mathrm{l}$ month, but average $\mathrm{CO}_{2}$ concentration under the tunnel remained unchanged $[438 \mathrm{ppm}(\mathrm{sE}=26)]$, probably because the flow rate of the gas itself was unchanged. After $\mathrm{CO}_{2}$ application was stopped in midOctober, $\mathrm{CO}_{2}$ concentration under the tunnel averaged $398 \mathrm{ppm}(\mathrm{SE}=15)$.

PLANT CONDITIONS BEFORE $\mathrm{CO}_{2}$ application. Before $\mathrm{CO}_{2}$ application, raspberry cane height and the number of canes in tunnels designated to receive $\mathrm{CO}_{2}$ were similar to 
Table 1. Photosynthesis parameters averaged from $0830 \mathrm{HR}$ to $1630 \mathrm{HR}$ at three heights in the canopy of raspberry plants under high tunnels near Camarillo, CA, in Mar. 2007 before carbon dioxide $\left(\mathrm{CO}_{2}\right)$ application. Data were analyzed using repeated-measures analysis with time as the repeated measure; the same letters within a column denote nonsignificant comparisons at $P<0.05$ using Duncan's multiple range test.

\begin{tabular}{lcccc}
\hline $\begin{array}{l}\text { Leaf ht } \\
\text { aboveground } \\
(\mathrm{cm})^{\mathbf{z}}\end{array}$ & $\begin{array}{c}\text { Photosynthetic } \\
\text { photon flux } \\
\left(\boldsymbol{\mu} \text { mol } \cdot \mathbf{m}^{-2} \cdot \mathrm{s}^{-1}\right)\end{array}$ & $\begin{array}{c}\text { Stomatal } \\
\text { conductance } \\
\left(\mathbf{m m o l} \cdot \mathbf{m}^{-2} \cdot \mathrm{s}^{-1}\right)\end{array}$ & $\begin{array}{c}\mathbf{C O}_{2} \\
\text { assimilation } \\
\left(\boldsymbol{\mu m o l} \cdot \mathbf{m}^{-2} \cdot \mathrm{s}^{-1}\right)\end{array}$ & $\begin{array}{c}\text { Leaf } \\
\text { fluorescence } \\
\left(\mathrm{F}_{\mathrm{v}} / \mathrm{F}_{\mathrm{m}}\right)\end{array}$ \\
\hline 40 & $346.7 \mathrm{c}$ & $252.6 \mathrm{~b}$ & $5.5 \mathrm{~b}$ & $0.80 \mathrm{a}$ \\
80 & $547.7 \mathrm{~b}$ & $302.9 \mathrm{a}$ & $8.6 \mathrm{a}$ & $0.78 \mathrm{~b}$ \\
120 & $857.5 \mathrm{a}$ & $329.7 \mathrm{a}$ & $5.3 \mathrm{~b}$ & $0.78 \mathrm{~b}$ \\
$P$ & $<0.0001$ & 0.0048 & 0.0038 & 0.0328 \\
\hline
\end{tabular}

${ }^{z} 1 \mathrm{~cm}=0.3937$ inch.

tunnels designated as untreated (data not shown). Yield in tunnels designated to receive $\mathrm{CO}_{2}$ was also similar to that of tunnels designated as controls (Table 3, $P=0.87$ ), but average berry weight and the number of baskets filled was $7 \%$ and $11 \%$ lower, respectively, in tunnels that would later receive $\mathrm{CO}_{2}$ compared with tunnels that would not (Table $3 ; P=$ 0.0001 and 0.001 , respectively). The smaller fruit and fewer baskets in tunnels designated to receive $\mathrm{CO}_{2}$ corresponded with the $27 \%$ reduction in average $\mathrm{CO}_{2}$ assimilation rates for these plants compared with those in tunnels randomly selected to be controls (Table 4, $P=0.03$ ); reduced photosynthesis may have reduced carbon availability for increasing fruit size. By contrast, $g_{s}$ and leaf fluorescence were similar among all tunnels (Table 4). The relative productivity of each tunnel before $\mathrm{CO}_{2}$ application was not considered when treatments were randomly assigned.

EFFECT OF $\mathrm{CO}_{2}$ ENRICHMENT. After $\mathrm{CO}_{2}$ application, yield from small plots and individual fruit weight in $\mathrm{CO}_{2}$ tunnels was $12 \%$ and $5 \%$ higher, respectively, than in untreated tunnels (Table $3 ; P=0.03$ and 0.0005 , respectively). By contrast, $\mathrm{CO}_{2}$ application did not affect the number of baskets (Table $3, P=$ 0.43 ), raspberry cane height, pruned cane biomass, cane diameter, or fruit carbohydrate content (data not shown), suggesting that increased carbon was used to increase fruit size rather than fruit quantity or chemical properties or cane size. Carbohydrate content of strawberry fruit grown in pots was similarly unaffected by $\mathrm{CO}_{2}$ enrichment to $1000 \mathrm{ppm}$ (AcuñaMaldonado and Pritts, 2008). $\mathrm{CO}_{2}$ enrichment also did not affect the height of two herbaceous skullcap (Scutellaria spp.) grown for medicinal purposes, but aboveground dry weight was increased $44 \%$ at a $\mathrm{CO}_{2}$ concentration of $1200 \mathrm{ppm}$ (Stutte et al., 2008). The $\mathrm{CO}_{2}$ concentration of about $400 \mathrm{ppm}$ in this study may have been too low to affect noncrop biomass accumulation. Interestingly, average strawberry size was not increased by $\mathrm{CO}_{2}$ concentrations higher than we achieved in our study for plants grown in pots in semiopen chambers (Acuña-Maldonado and Pritts, 2008) or field-grown under tunnels (Hartz et al., 1991).

It is important to view these modest increases in yield and berry weight in the context of previous harvests in this semiperennial cropping system: if 'Titan' red raspberry was prevented from producing a full crop in 1 year, yields tended to be higher than normal in the following year (Fernandez and Pritts, 1996). The larger fruit size and similar number of fruit baskets for $\mathrm{CO}_{2}$-treated plants compared with untreated therefore may be a result of smaller fruit size and fewer baskets filled before treatment. However, yield in small plots by weight rather than by number was similar in all tunnels before treatment in May and June but was higher in September and October after receiving $\mathrm{CO}_{2}$, suggesting some influence of treatment rather than simply prior yield.

$P P F, g_{S}, \mathrm{CO}_{2}$ assimilation, and leaf fluorescence were similar for plants in $\mathrm{CO}_{2}$ and untreated tunnels in June at the start of $\mathrm{CO}_{2}$ application and in September near the end of $\mathrm{CO}_{2}$ application (Table 4). These static measures could not account for the differences in yield and fruit size. Floricane leaf photosynthetic rates measured in a similar fashion for 'Titan'-before, during, and after fruiting-were also unaffected by treatments as extreme as full canopy shading, primocane removal, or flower removal (Fernandez and Pritts, 1996). Instead, if plant physiological parameters were measured during the course of the entire day as they were before $\mathrm{CO}_{2}$ was applied and for the full growing cycle, differences between treatments may have been

Table 2. Ambient air temperature at three heights on the outer surface of the canopy of raspberry plants under high tunnels before $\mathrm{CO}_{2}$ application. Values reported at each hour are the mean result for measurements made on one leaf at each height on each of three plants along the trellis in two separate tunnels $(n=6)$.

\begin{tabular}{|c|c|c|c|c|c|c|c|c|c|c|}
\hline \multirow{4}{*}{$\begin{array}{l}\text { Leaf ht } \\
(\mathrm{cm} \text { aboveground })^{\mathrm{z}}\end{array}$} & \multicolumn{9}{|c|}{ Time of day } & \multirow[b]{4}{*}{$P($ row $)$} \\
\hline & \multicolumn{9}{|c|}{ HR } & \\
\hline & 0830 & 0930 & 1030 & 1130 & 1230 & 1330 & 1430 & 1530 & 1630 & \\
\hline & \multicolumn{9}{|c|}{ Air temp $\left({ }^{\circ} \mathrm{C}\right)^{\mathrm{y}}$} & \\
\hline 40 & $14.75 \mathrm{~b} \mathrm{H}^{\mathrm{x}}$ & $18.2 \mathrm{c} \mathrm{G}$ & $21.2 \mathrm{c} \mathrm{F}$ & $22.2 \mathrm{c} \mathrm{E}$ & $25.4 \mathrm{c} \mathrm{C}$ & $27.3 \mathrm{~b} \mathrm{~A}$ & $26.0 \mathrm{~b} \mathrm{~B}$ & $23.5 \mathrm{c} \mathrm{D}$ & $20.6 \mathrm{c} \mathrm{F}$ & $<0.0001$ \\
\hline 80 & 14.78 b I & $18.3 \mathrm{~b} \mathrm{H}$ & $21.4 \mathrm{~b} \mathrm{~F}$ & $22.4 \mathrm{~b} \mathrm{E}$ & $25.5 \mathrm{~b} \mathrm{c}$ & $27.5 \mathrm{a} \mathrm{A}$ & 26.3 а в & $23.6 \mathrm{~b} \mathrm{D}$ & 20.7 b G & $<0.0001$ \\
\hline 120 & $14.93 \mathrm{a} \mathrm{I}$ & $18.4 \mathrm{a} \mathrm{H}$ & $21.6 \mathrm{a} \mathrm{F}$ & $22.5 \mathrm{a} \mathrm{E}$ & 25.7 a c & $27.6 \mathrm{a} \mathrm{A}$ & 26.4 а в & 23.7 a D & 20.9 a G & $<0.0001$ \\
\hline
\end{tabular}

${ }^{\mathrm{z}} 1 \mathrm{~cm}=0.3937$ inch.

${ }^{\mathrm{y}}\left(1.8 \times{ }^{\circ} \mathrm{C}\right)+32={ }^{\circ} \mathrm{F}$

xThe same letters in a vertical column denote nonsignificant comparisons at $P<0.05$ using Fisher's protected least significant difference (LSD) test. The same letters in a horizontal row denote nonsignificant comparisons at $P<0.05$ using Fisher's protected LSD test. 
Table 3. Relative yield, fruit weight, and number of fruit baskets harvested from raspberry plants grown under tunnels before and after carbon dioxide $\left(\mathrm{CO}_{2}\right)$ application in 2007. Data for the $\mathrm{CO}_{2}$ treatment are reported as percentages of the untreated control in accordance with an agreement made with our grower collaborator.

\begin{tabular}{|c|c|c|c|c|c|c|}
\hline \multirow[b]{2}{*}{ Tunnel } & \multicolumn{2}{|c|}{ Total $w^{\mathrm{z}}$} & \multicolumn{2}{|c|}{ Wt per berry ${ }^{\mathrm{y}}$} & \multicolumn{2}{|c|}{ Baskets (no.) ${ }^{\mathrm{x}}$} \\
\hline & Before $\mathrm{CO}_{2}{ }^{\mathrm{w}}$ & After $\mathrm{CO}_{2}{ }^{\mathrm{v}}$ & Before $\mathrm{CO}_{2}$ & After $\mathrm{CO}_{2}$ & Before $\mathrm{CO}_{2}$ & After $\mathrm{CO}_{2}$ \\
\hline $\mathrm{CO}_{2}$ & $99 \% \mathrm{a}^{\mathrm{u}}$ & $112 \%$ a & $93 \% \mathrm{~b}$ & $105 \%$ a & $89 \%$ b & $103 \%$ a \\
\hline$P$ & 0.87 & 0.03 & 0.0001 & 0.0005 & 0.001 & 0.43 \\
\hline
\end{tabular}

${ }^{2}$ Yield was averaged from two 20 - $\mathrm{ft}(6.1 \mathrm{~m})$ plots per tunnel (three replicate tunnels per treatment; $\mathrm{n}=12$ ) before conversion to percentage.

y Subsamples of 25 berries were weighed from two 20 - $\mathrm{ft}$ plots per tunnel before conversion to percentage.

${ }^{x}$ Number of baskets filled from the full tunnel $[300 \mathrm{ft}(91.4 \mathrm{~m})]$ before conversion to percentage. Each basket was $6 \mathrm{oz}(170.1 \mathrm{~g})$.

wharvest period before $\mathrm{CO}_{2}$ application was 26 May to 15 June.

"Harvest period after $\mathrm{CO}_{2}$ application was 12 Sept. to $30 \mathrm{Oct}$.

"The same letters within a column denote nonsignificant comparisons at $P<0.05$ with the overall error rate controlled by Tukey-Kramer adjustment.

Table 4. Carbon dioxide $\left(\mathrm{CO}_{2}\right)$ assimilation, $\mathfrak{g}_{\mathrm{S}}$, and leaf fluorescence (ratio of variable fluorescence to maximum fluorescence) before $\mathrm{CO}_{2}$ application to raspberry grown under high tunnels (January), at the start of $\mathrm{CO}_{2}$ application (June), and at the end of $\mathrm{CO}_{2}$ application (September) in 2007. Leaves were measured at three canopy heights and averaged.

\begin{tabular}{|c|c|c|c|c|c|c|c|c|c|}
\hline \multirow[b]{2}{*}{ Treatment } & \multicolumn{3}{|c|}{$\mathrm{CO}_{2}$ assimilation $\left(\mu \mathrm{mol} \cdot \mathrm{m}^{-2} \cdot \mathrm{s}^{-1}\right)$} & \multicolumn{3}{|c|}{ Stomatal conductance $\left(\mathrm{mmol} \cdot \mathrm{m}^{-2} \cdot \mathrm{s}^{-1}\right)$} & \multicolumn{3}{|c|}{ Leaf fluorescence $\left(\mathrm{F}_{\mathrm{v}} / \mathrm{F}_{\mathrm{m}}\right)$} \\
\hline & Jan. & June & Sept. & Jan. & June & Sept. & Jan. & June & Sept. \\
\hline $\mathrm{CO}_{2}$ & $4.7 b^{z}$ & $2.6 \mathrm{a}$ & $2.8 \mathrm{a}$ & $25.3 \mathrm{a}$ & $34.0 \mathrm{a}$ & $25.8 \mathrm{a}$ & $0.68 \mathrm{a}$ & $0.72 \mathrm{a}$ & $0.74 \mathrm{a}$ \\
\hline$P$ & 0.03 & 0.28 & 0.77 & 0.68 & 0.12 & 0.71 & 0.74 & 0.10 & 0.38 \\
\hline
\end{tabular}

${ }^{2}$ The same letters within a column denote nonsignificant comparisons at $P<0.05$ with the overall error rate controlled by Tukey-Kramer adjustment.

captured. A carbon budget estimating net seasonal $\mathrm{CO}_{2}$ assimilation in the plant canopy may be much more closely correlated to crop yield compared with instantaneous measurements (Zelitch, 1982). We also note that other raspberry varieties, whether public or private, may respond differently to $\mathrm{CO}_{2}$ application compared with the proprietary variety used in this study: Stafne et al. (2000) measured a wide range of $\mathrm{CO}_{2}$ assimilation rates among raspberry genotypes sourced from the southern and northwestern United States, Japan, China, and South Korea, and Keep (1972) found wide variation in physiological and morphological traits was among wild populations at 12 locations across Europe.

Increasing $\mathrm{CO}_{2}$ application to 12 $\mathrm{h}$ per day with the same gas flow rate did not significantly increase $\mathrm{CO}_{2}$ concentration under the tunnel, but may increase $\mathrm{CO}_{2}$ assimilation, which, unlike $g_{s}$, was not reduced during the midday. Most, if not all, controlled studies increased the $\mathrm{CO}_{2}$ concentration rather than the duration of application, which increased raspberry photosynthesis as long as light was not limiting (Fernandez and Pritts, 1994; Percival et al., 1996): other methods to increase $\mathrm{CO}_{2}$ concentration inside the tunnel, such as closing the ends or using multiple delivery lines, could be future avenues of investigation.

Our preliminary study demonstrates some potential benefits of $\mathrm{CO}_{2}$ application for field-grown raspberry under high tunnels. We hope these results and subsequent research stimulate further development of waste$\mathrm{CO}_{2}$ recycling technology, enabling progressive agricultural producers to improve the quality of their crops while contributing to a viable solution to greenhouse gas emissions and to the sustainability of their operations.

\section{Literature cited}

Acuña-Maldonado, L.E. and M.P. Pritts. 2008. Carbon and nitrogen reserves in perennial strawberry affect plant growth and yield. J. Amer. Soc. Hort. Sci. 133:735-742.

Brownscombe, T. 2006. The capture program for phase II (2004-2008). 22 Jan. 2009. <http://www.co2captureproject. org/allresults.php?pubcategory=capture $>$.

California Department of Food and Agriculture. 2007. Berry acreage, production and value, 1997-2006, p.68. In: California Agricultural Resource Directory 2007. 22 Jan. 2009. <http://www.cdfa. ca.gov/statistics/>.

Carpentier, R. 2005. Influence of high light intensity on photosynthesis: Photo- inhibition and energy dissipation, p. 327342. In: M. Pessarakli (ed.). Handbook of photosynthesis. 2nd ed. Taylor and Francis, New York.

$\mathrm{CO}_{2}$ Capture Project. 2008. About $\mathrm{CO}_{2}$ storage. 22 Jan. 2009. <http://www.co2 captureproject.org/about_storage.html $>$.

Dale, A., A. Sample, and E.M. King. 2003. Scheduling primocane fruiting raspberries for year-round production in greenhouses. Acta Hort. 626:219-223.

Daugovish, O. and K.D. Larson. 2009. Strawberry production with protected culture in southern California. ISHS Acta Hort. 842:163-166.

Fernandez, G.E. and M.P. Pritts. 1994. Growth, carbon acquisition, and sourcesink relationships in 'Titan' red raspberry. J. Amer. Soc. Hort. Sci. 119:1163-1168.

Fernandez, G.E. and M.P. Pritts. 1996. Carbon supply reduction has a minimal influence on current year's red raspberry (Rubus ideaus L.) fruit production. J. Amer. Soc. Hort. Sci. 121:473-477.

Friedrich, H., C.R. Rom, J. McAfee, M.E. Garcia, D.T. Johnson, J.S. Popp, and C. Vincent. 2009. Performance of high tunnel organic blackberry and raspberry. HortScience 44:1114. (Abstr.).

Gaskell, M. 2004. Field tunnels permit extended season harvest of small fruits in California. Acta Hort. 659:425-430.

Hanson, E., M. VonWeihe, R. Isaacs, and A. Schilder. 2008. Tunnel culture of 
raspberries in Michigan. 20 Aug. 2009. <http://www.maes.msu.edu/swmrec/ publicationsfolder/Annualreports / 08annualrpt/Tunnel\%20RPT\%20Hanson\% 2008.pdf>.

Hartz, T.K., A. Baameur, and D.B. Holt. 1991. Carbon dioxide enrichment of high-value crops under tunnel culture. J. Amer. Soc. Hort. Sci. 116:970-973.

Heidenreich, C., M. Pritts, M.J. Kelly, and K. Demchak. 2008. High tunnel raspberries and blackberries. Cornell University Department of Horticulture Publication 47.20 Aug. 2009. <http://www. fruit.cornell.edu/Berries/bramblepdf/ High\%20Tunnel\%20Production-2008\% 20rev.pdf $>$.

Keep, E. 1972. Variability in the wild raspberry. New Phytol. 71:915-924.

Miracca, I. 2006. Carbon dioxide capture project 2 capture strategies. 22 Jan. 2009. <http://www.co2captureproject.org/ allresults.php?pubcategory=capture $>$.

Oliveira, P.B., C.M. Oliveira, L. Lopesda-Fonseca, and A.A. Monteiro. 1996. Off-season production of primocane fruiting red raspberry using summer prun- ing and polyethylene tunnels. HortScience 31:805-807.

Percival, D.C., J.T.A. Proctor, and M.J. Tsujita. 1996. Whole-plant net $\mathrm{CO}_{2}$ exchange of raspberry as influenced by air and root-zone temperature, $\mathrm{CO}_{2}$ concentration, irradiation, and humidity. J. Amer. Soc. Hort. Sci. 121:838-845.

Ralph, P. 2005. Fluorescence. 14 Nov. 2008. <http://www.science.uts.edu.au/des/ StaffPages/PeterRalph/fluorescence. html>.

Sauerbeck, D.R. 2001. $\mathrm{CO}_{2}$ emissions and $\mathrm{C}$ sequestration by agriculture: Perspectives and limitations. Nutr. Cycl. Agroecosyst. 60:253-266.

Schreiber, U. 2004. Pulse-amplitude modulation (PAM) fluorometry and saturation pulse method: An overview, p. 279-319. In: G.C. Papageorgiou and Govindjee (eds.). Chlorophyll a fluorescence: A signature of photosynthesis. Advances in Photosynthesis and Respiration 19. Springer, Dordrecht, The Netherlands.

Stafne, E.T., J.R. Clark, and C.R. Rom. 2000. Leaf gas exchange characteristics of red raspberry germplasm in a hot environment. HortScience 35:278-280.

Stutte, G.W., I. Eraso, and A.M. Rimando. 2008. Carbon dioxide enrichment enhances growth and flavonoid content of two Scutellaria species. J. Amer. Soc. Hort. Sci. 133:631-638.

U.S. Department of Agriculture. 1997. Hueneme series. Official soil series descriptions. 8 July 2009. <http://soils.usda. gov/technical/classification/osd/index. html>.

U.S. Environmental Protection Agency. 2008. Inventory of U.S. greenhouse gas emissions and sinks, 1996-2006. 22 Jan. 2009. <http://epa.gov/climatechange/ emissions/usinventoryreport.html $>$.

Wang, S.Y., J.A. Bunce, and J.L. Maas. 2003. Elevated carbon dioxide increases contents of antioxidant compounds in field grown strawberries. J. Agr. Food Chem. 51:4315-4320.

Zelitch, I. 1982. The close relationship between net photosynthesis and crop yield. Bioscience 32:796-802. 